\title{
Relationship Between Perceived Social Support and Attitudes Towards Menopause among Women and Affecting Factors
}

\author{
Nülüfer Erbil ${ }^{1}$, Mehtap Gümüşay ${ }^{2}$ \\ ${ }^{1}$ Department of Gynecology and Obstetrics Nursing, Faculty of Health Sciences, Ordu University, Ordu, Turkey \\ ${ }^{2}$ Department of Women Health and Diseases Nursing, İstanbul University Faculty of Nursing, İstanbul, Turkey \\ Received: 24 April 2018, Accepted 20 August 2018, Published online: 30 August 2018 \\ (C) Ordu University Institute of Health Sciences, Turkey, 2018
}

\begin{abstract}
Objective: The aim of the study was to investigate affecting factors on perceived social support and attitudes towards menopause and the relationship between perceived social support and attitudes towards menopause of Turkish women.

Methods: The study was planned as a descriptive and cross-sectional design. The data were collected with questionnaire form, Multidimensional Scale of Perceived Social Support and Attitudes towards Menopause Scale.

Results: A majority of women $(66.7 \%)$ had a negative attitude towards menopause. Strong perceived social support positively affects women's attitudes towards menopause. Woman who have higher education level, being age 50 and under, working, being single, having normal BMI, and being in a nuclear family had more positive attitude towards menopause. Other factors were a husband who is a civil servant and with higher education, having a higher income perception and positive health perception, living in a province, physical exercise, being premenopausal, being informed about menopause. The perceived social support scale scores were higher than for other women in the following categories: age 50 and under, higher education level, working, higher income perception, single, living in a province, physical exercise, and positive health perception.

Conclusion: In conclusion, the majority of women had negative attitudes toward menopause and perceived social support during menopause was at low levels. The perceived social support and attitude towards menopause correlated. Informational programs need to be focused on developing positive attitudes in both women and men to help couples and strengthening women's social support and preparation during menopause.
\end{abstract}

Key words: Menopause attitude, perceived social support, menopause, affecting factors

Address for correspondence/reprints:

Nülüfer Erbil

Telephone number: +90 (452) 23450 10- 5531

E-mail: nerbil@odu.edu.tr

DOI: $10.19127 / \mathrm{mbsjohs} .417940$

Note: This study was presented as a poster presentation in 14th ESC Congress/2nd Global ESC Conference, 4-7 May 2016, in Basel, Switzerland.

\section{Introduction}

Natural menopause is defined as the permanent cessation of menstruation due to loss of ovarian follicular activity and is recognized to have occured after 12 consecutive months of amenorrhea, for which there is no other obvious cause (International Menopause Society, 2016). The reproductive period before the perimenopause is referred to as premenopause. The menopausal process is affected by biological, psychological, and socio-cultural factors. It signifies the end of the reproductive period and transition to the post-reproductive period which 
begins on average at ages $40-45$ years and lasts until about 65 years of age (Taskin, 2015). During this time, women experience a number of changes and complaints which are due to declining levels of estrogen. Some of these changes and complaints include cycle disorders, hot flashes, night sweats, sleep disturbances and vaginal dryness (Tortumluoğlu, 2004).

Affected factors on the perception and attitudes towards menopause and menopausal symptoms are include ethnicity, traditions, society and the value given to the elderly. Furthermore, social roles, sexuality, life philosophy, cultural features (Tortumluoğlu, 2004), education level, and women's marital, menopausal, and job status also affect society's attitudes towards menopause (Jassim and Al-Shboul, 2008). Previous studies have shown that there are differences between cultures and within cultures regarding menopause perception and attitudes (Huffman, Myers, Tingle and Bond, 2005; Vural and Yangin, 2016;).

Studies have compared Eastern and Western cultures and have demonstrated that menopausal women living in Eastern cultures viewed menopause as a natural process, and they held more positive views than women living in the West (Koc and Saglam, 2008). A study on Iranian women found that women's menopausal attitudes in rural areas were more negative than women in urban areas (Khademi and Cooke, 2003). Another study in Nigeria found that perceptions and attitudes regarding menopause of women from four different ethnic groups differed (Adewuyi and Akinade, 2010). Studies on the attitudes of Turkish women have revealed that women had negative attitudes toward menopause (Tortumluoğlu and Erci, 2004; Erbil et al., 2012; Şentürk Erenel et al., 2015), yet other studies noted women's positive attitudes toward menopause (Coban et al., 2008; Akkuzu et al., 2009).

Social support is defined as the perception or experience that one is loved and cared for by others, esteemed and valued, and part of a social network of mutual assistance and obligations (Taylor, 2011). Social support may come from a partner, relatives, friends, coworkers, social and community ties, and even a devoted pet (Taylor, 2011). Social support can be formal, informal, social, professional, structured, or unstructured, and it may affect the general well-being of individuals living with chronic and life threatening health conditions (Yoo et al., 2010). Perceived social support is the individuals' understanding of love and the support that they receive from their family, friends, and relatives
(Najafabadi et al., 2015). Spouses, friends and support groups are thought to be a positive influence during the menopause process (Taskin, 2015). Therefore, the social support factor is considered to exert a positive effect on women's menopause perceptions and attitudes. Sufficent and strong social support can help women address the grief of the losses experienced during the climacteric period (Zhang et al., 2016). A previous the study indicated significant and negatively relationship between perceived social support and depression in Iranian postmenopausal women (Najafabadi et al., 2015). A study in Turkey found increased marital adjustment scores were associated with decreased menopausal symptoms of women (Coban et al., 2008).

In Turkey, there is limited research investigating the association between attitudes towards menopause and perceived social support during this time of physical and emotional changes. This study was conducted to investigate the relationship between perceived social support and attitudes towards menopause of Turkish women ages 45 and older and to determine affecting factors on attitude and perceived social support.

Questions of this research:

- What are women's attitudes towards menopause and their perceived social support?

- Is there a relationship between attitudes towards menopause and perceived social support?

- What are the related factors regarding women's attitudes towards menopause and perceived social support?

\section{Methods}

\section{Study design and Sample}

The study was conducted as a descriptive and cross-sectional design. The sample of this study was included 93 women who were all aged 45 and older and volunteered to participate. The study was performed between 29 December 2014 and 19 June 2015 at gynecology outpatient clinic of a public health in northeast of Turkey.

\section{Data Collection}

The data were collected with questionnaire form, Multidimensional Scale of Perceived Social Support (MSPSS) and Attitudes towards Menopause Scale. Menopausal status of participants was defined as follow: Premenopausal period is defined regular or irregular menstruation or the last menstrual bleeding occured $>3$ and $<12$ months prior to the study. Women who have not menstruated within the previous 12 months are categorized as postmenopausal (Cheng et al., 2005). 


\section{Questionnaire Form}

The questionnaire form had two parts with questions about women's socio-demographic obstetric characteristics, knowledge and behaviours with menstruation and menopause. The first part of the questionnaire asked about age, weight, height marital status, duration of marriage, number of pregnancy number of child, education level, occupation, family type, husband's being alive, husband education level and occupation, place of residence, family income, social insurance and having a chronic disease. The second part of the questionnaire asked about their menarche age, whether dysmenorrhoea was experienced during menstruation, having physicial problems during menstruation, the last menstruation time, menopausal status, having gynecological problems, having gynecological operation, whether menopause was experienced natural or surgical, having knowledge about menopause, whether a doctor had been consulted because of menopause, using hormone replacement therapy, whether traditional therapy was used for menopausal problems, using oral contraception, whether husband support was got for menopausal complaints, using permanent drug, smoking cigarettes, physicial exercise habit, whether anyone need of care was in family and thoughts about their health (Erbil et al., 2012; Şentürk Erenel et al., 2015; Çoban et al., 2008; Akkuzu et al., 2009).

\section{Attitudes Towards Menopause Scale}

Attitudes Towards Menopause Scale (ATMS) can be used to evaluate attitudes towards menopause of women who are experiencing menopause or not yet in menopause. ATMS was developed by Neugarten et al. in 1963. Turkish version of ATMS was adapted and revised by Uçanok and Bayraktar in 1996. There were 18 negative and 2 positive items on the scale. For positive items, "I definitely don't agree" rated a score of 0 points; "I don't agree answer" scored 1 points; "I am not sure" answer scored 2 points; "I agree" answer scored 3 points; "I definitely agree" answer scored 4 points. The score of negative items of the scale were reversed. The highest score of the scale was 80 and the lowest score was zero. The cut of point of the scale was 40 points. Women who receive 40 points or higher have a positive attitude. Cronbach's alpha reliability coefficient in Turkish version was 0.86 (Uçanok \& Bayraktar, 1996). In this study, Chronbach Alpha value of ATMS was found 0.73 .

\section{Multidimensional Scale of Perceived Social Support}

The Multidimensional Scale of Perceived Social Support (MSPSS) by Zimet and collegues (1988) evaluates perceived adequacy of social support from 3 sources: family, friends, and significant other (Zimet et al., 1998). Twelve-item ratings are made on a 7-point Likert-type scale ranging from very strongly disagree (1 point) to very strongly agree (7 points). The scale scores for the MSPSS can range from 12 to 84, with higher scores indicating higher perceived levels of social support. Three separate scores can be calculated for the sources of support; Significant other scale items are 1,2, 5, 10 numerous items; Family scale items are 3, 4, 8, 11 numerous items; and Friends scale items are 6, 7, 9, 12 numerous items. In addition, the total of all items indicates total perceived social support grades. The reliability and validity of Turkish version of the MSPSS instrument was established by Eker and Arkar (2001). Eker and Arkar determined Cronbach's alpha reliability coefficients are 0.92 for significant other, 0.80 for family, 0.85 for friends, 0.83 for total MSPSS. In this study, Cronbach's alpha reliability coefficients were found as 0.95 for significant other, 0.91 for family, 0.87 for friends, 0.90 for total MSPSS.

\section{Statistical Methods}

The data was analyzed using descriptive statistics methods including frequency, percentage, arithmetic mean, standard deviation, range, maximum, minimum scores. The t-test, Kruskal-Wallis test and Mann-Whitney U test were used as descriptive analysis to determine an association between dependent and independent variables. After Kruskal Wallis analysis, Mann Whitney $U$ test with Bonferroni correction was used to determine the group in which the difference occurred. The Pearson's correlation analysis test was used to determine the relation between MSPSS and ATMS scores and continuous independent variables. The reliability was evaluated using the Cronbach's alpha reliability coefficient. The statistical significance was set $\mathrm{p}<0.05$.

\section{Results}

This study was conducted 93 women with who 45 ages and older. The average age of the women was $51.21 \pm 4.71$ (range $45-60$ ) and $53.8 \%$ of them were in the 45-50 age group, average menarche age of women was 12.75 \pm 1.22 years (range 11-16), average number of pregnancies was $3.50 \pm 1.46(1-9)$ 
$(\mathrm{n}=86)$, their number of children was $3.13 \pm 1.22$ (range 1-7) $(\mathrm{n}=86)$, their duration of marriage was $29.32 \pm 6.06$ years (range 17-41) $(\mathrm{n}=77)$, last menstruation duration of women transition to menopause was $6.74 \pm 3.19$ years (range $1-15$ ).

It was determined that $31.2 \%$ of them graduated from primary school, $66.7 \%$ of them were housewifes, $72 \%$ of women were married, $71 \%$ of them had nucleus family, $41.8 \%$ of their husbands graduated from high school, majority of their husbands were self-employment (37.4\%), $90.3 \%$ of them had social security, $65.6 \%$ of them had "middle" income perception, $63.4 \%$ of women lived in province and $43 \%$ of them were in overweight groups (see Table 4).

Thirty three percent women had a chronic disease, $33.3 \%$ of them used a drug, $26.9 \%$ of them smoked cigarettes, $31.2 \%$ of them done physical exercise, $18.3 \%$ of them had someone in need of your care in the family, $64.5 \%$ of them evaluated as good self-health. $31.2 \%$ of them had dysmenorrhea, over half of women $(64.5 \%)$ were in postmenopausal period, majority of women were natural menopause (86\%), $52.7 \%$ of them received information about menopause, $33.3 \%$ of them had a spousal support related menopause (see Table 5).

It was determined that ATMS mean score was $36.31 \pm 7.75$ (range 18-56), family subscale mean score was $21.61 \pm 4.43$ (range 4-28), friend subscale mean score was 18.40 \pm 3.99 (range 6-26) and significant other subscale mean score was $14.91 \pm 6.32$ (range 4-26) of MSPSS. The average total MSPSS score of social support scale was $54.93 \pm 11.63$ (range 22-77) (see Table 1).

The results of this study revealed that $66.7 \%$ of the women had a negative attitude towards menopause and their mean score $(31.87 \pm 4.77)$ was lower than women with positively attitude. The family support $(20.93 \pm 4.75)$, friend support $(17.66 \pm 4.30)$ and significant other support (13.66 \pm 5.98$)$ and total MSPSS score means $(52.25 \pm 11.71)$ of women who had negatively attitude towards menopause were lower than women with positively attitude and differences were statistically significant (respectively, $\mathrm{p}=.037$, $\mathrm{p}=.010, \mathrm{p}=.000, \mathrm{p}=.001$ ), (see Table 2).

The statistically positively significant correlations were found between total MSPSS scores $(\mathrm{r}=.443)$, family support subscale $(\mathrm{r}=.404)$, friend support $(\mathrm{r}=.389)$, significant other support $(\mathrm{r}=.285)$ and attitude towards menopause scale score of women (see Table 3 ). Also, the positively significant correlations were found between scores of attitudes towards menopause and age ( $\mathrm{r}=.-342)$, duration of marriage ( $\mathrm{r}=-.388)$, number of pregnancies $(\mathrm{r}=-341)$, number of children $(\mathrm{r}=-.325)$, duration of menopause $(\mathrm{r}=-269)$, and menarche age was no correlated (see Table 5). In addition to, the negatively significant correlations were found between scores of total MSPSS and age ( $r=-301)$, duration of marriage ( $r=-$ .398), number of pregnancies ( $\mathrm{r}=-.420)$ number of children ( $\mathrm{r}=-.386)$ was significant, and menarche age and duration of menopause were no correlated (see Table 4).

Women's the ATMS average scores according to age groups $(\mathrm{p}=.020)$, educational level $(\mathrm{p}=.000)$, working status $(\mathrm{p}=.001)$, marital status $(\mathrm{p}=.001)$, family type $(\mathrm{p}=.036)$, husband's education level $(p=.013)$, husband's working status $(p=.039)$, income perception $(\mathrm{p}=.006)$, place of residence $(\mathrm{p}=$ $.001)$, body mass index groups $(\mathrm{p}=.000)$, physical exercise status $(\mathrm{p}=.010)$, perception of health $(\mathrm{p}=.000)$, menopausal status $(\mathrm{p}=.010)$, information about menopausal ( $\mathrm{p}=.039)$ were compared and the differences between groups were statistically significant (see Table 4,5).

The MSPSS average scores according to age groups $(\mathrm{p}=.029)$, education level $(\mathrm{p}=.000)$, working status ( $\mathrm{p}=.002)$, marital status $(\mathrm{p}=.003)$, the income perception $(\mathrm{p}=.012)$, place of residence $(\mathrm{p}=.000)$, physical exercise status $(\mathrm{p}=.004)$, perception of health $(\mathrm{p}=.023)$ and information about menopausal $(p=.008)$ of women were compared and the differences between groups were statistically significant (see Table 4,5). 


\section{Perceived Social Support and Menopause Attitude}

Table 1. Cronbach alpha values and mean, minimum, maximum scores of ATMS, MSPSS and its subscales

\begin{tabular}{lccccc}
\hline Scales & $\begin{array}{c}\text { Scales min- } \\
\text { max values }\end{array}$ & $\begin{array}{c}\text { Marked } \\
\text { min-max } \\
\text { values }\end{array}$ & $\begin{array}{c}\text { Scale } \\
\text { mean }\end{array}$ & $\begin{array}{c}\text { SD } \\
\text { Cronbach } \\
\text { Alpha }\end{array}$ \\
\hline ATMS & $0-80$ & $18-56$ & 36.31 & 7.75 & .73 \\
MSPSS & $12-84$ & $22-77$ & 54.93 & 11.63 & .90 \\
Family subscale of MSPSS & $4-28$ & $4-28$ & 21.61 & 4.43 & .91 \\
Friends subscale of MSPSS & $4-28$ & $6-26$ & 18.40 & 3.99 & .87 \\
Significant other subscale of MSPSS & $4-28$ & $2-26$ & 14.91 & 6.32 & .95 \\
\hline
\end{tabular}

Table 2. Differences of women's MAS and MSPSS with subscales scores and distribution of women according to intensity of attitude towards menopause

\begin{tabular}{|c|c|c|c|c|c|c|c|}
\hline ATMS score & $\mathbf{n}$ & $\%$ & $\begin{array}{c}\text { ATMS } \\
\operatorname{mean} \pm \text { SD }\end{array}$ & $\begin{array}{c}\text { F amily } \\
\text { subscale } \\
\text { mean } \pm S S\end{array}$ & $\begin{array}{c}\text { Friend } \\
\text { Subscale } \\
\text { mean } \pm \text { SS }\end{array}$ & $\begin{array}{c}\text { Significant } \\
\text { other } \\
\text { subscale } \\
\text { mean } \pm \text { SS }\end{array}$ & $\begin{array}{l}\text { MSPSS } \\
\text { mean } \pm \text { SS }\end{array}$ \\
\hline Negative attitude (0-39) & 62 & 66.7 & $31.87 \pm 4.77$ & $20.93 \pm 4.75$ & $17.66 \pm 4.30$ & $13.66 \pm 5.98$ & $52.25 \pm 11.71$ \\
\hline Positive attitude (40-80) & 31 & 33.3 & $45.19 \pm 3.96$ & $22.96 \pm 3.41$ & $19.90 \pm 2.79$ & $17.41 \pm 6.33$ & $60.29 \pm 9.57$ \\
\hline Total & 93 & 100.0 & $36.31 \pm 7.75$ & $21.61 \pm 4.43$ & $18.40 \pm 3.99$ & $14.91 \pm 6.32$ & $54.93 \pm 11.63$ \\
\hline$P$ value & & & $\begin{array}{c}\mathrm{t}=-13.383 \\
\mathrm{p}=.000\end{array}$ & $\begin{array}{c}\mathrm{t}=-2.121 \\
\mathrm{p}=.037\end{array}$ & $\begin{array}{c}\mathrm{t}=-2.630 \\
\mathrm{p}=.010\end{array}$ & $\begin{array}{c}\mathrm{t}=-13.383 \\
\mathrm{p}=.000\end{array}$ & $\begin{array}{c}\mathrm{t}=-3.302 \\
\mathrm{p}=.001\end{array}$ \\
\hline
\end{tabular}

Table 3. The correlations between Attitudes towards Menopause Scale, MSPSS and its subscales scores and continuous variables

\begin{tabular}{|c|c|c|c|c|c|}
\hline \multirow[t]{2}{*}{ Variables } & $\begin{array}{c}\text { Attitudes } \\
\text { towards } \\
\text { Menopause } \\
\text { Scale } \\
\end{array}$ & $\begin{array}{c}\text { F amily } \\
\text { subscale }\end{array}$ & $\begin{array}{c}\text { Friend } \\
\text { Subscale }\end{array}$ & $\begin{array}{c}\text { Significant } \\
\text { other } \\
\text { subscale } \\
\text { score } \\
\end{array}$ & $\begin{array}{l}\text { MSPSS totally } \\
\text { Score } \\
\end{array}$ \\
\hline & $\mathbf{r}$ & $\mathbf{r}$ & $\mathbf{r}$ & $\mathbf{r}$ & $\mathbf{r}$ \\
\hline Attitudes towards Menopause Scale & - & $.404^{* *}$ & $.389^{* *}$ & $.285^{* *}$ & $.443^{* *}$ \\
\hline Family subscale & $.404^{* *}$ & - & $.391^{* *}$ & $.271^{* * *}$ & $.663^{* *}$ \\
\hline Friends subscale & $.389^{* *}$ & $.391^{* *}$ & - & $.607^{* *}$ & $.822^{* * *}$ \\
\hline Significant other subscale & $.285^{* *}$ & $.271^{* *}$ & $.607^{* *}$ & - & $.855^{* *}$ \\
\hline MSPSS & $.443^{* *}$ & $.663^{* *}$ & $.822^{* *}$ & $.855^{* *}$ & - \\
\hline Women'age (n=93) & $-.342^{* *}$ & $-.224^{*}$ & $-.369^{* *}$ & -.163 & $-.301^{* *}$ \\
\hline Menarche age $(n=93)$ & .029 & .100 & .074 & .013 & .071 \\
\hline Duration of marriage $(n=77)$ & $-.388^{* *}$ & -.182 & $-.441^{* *}$ & $-.320^{* *}$ & $-.398^{* *}$ \\
\hline Number of pregnancy $(n=86)$ & $-.341^{* *}$ & -.171 & $-.398^{* *}$ & $-.408^{* *}$ & $-.420^{* *}$ \\
\hline Number of child $(\mathrm{n}=86)$ & $-.325^{* *}$ & -.092 & $-.388^{* *}$ & $-.404^{* *}$ & $-.386^{* *}$ \\
\hline Duration of menopause & $-.269^{*}$ & $-.271^{*}$ & -.250 & -.002 & -.193 \\
\hline
\end{tabular}

$r$ : Pearson's correlation coefficient

*Correlation is significant at the 0.05 level

** Correlation is significant at the 0.01 level 
Table 4. Differences of MSPSS and ATMS scores according to socio-demographic variables of women $(n=93)$

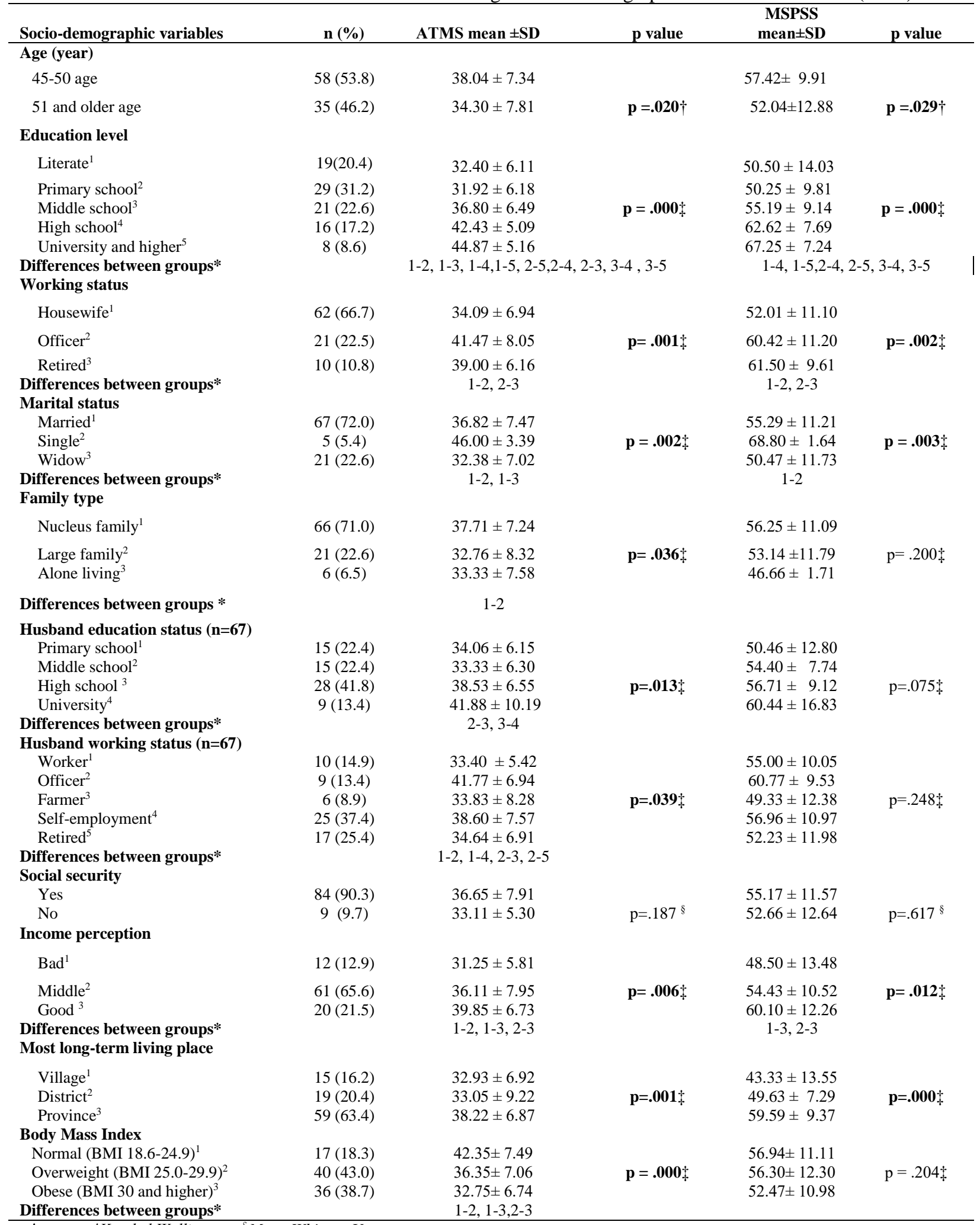

$\dagger t$ test., $\ddagger$ Kruskal Wallis test., $\$$ Mann Whitney-U test,

* It was used Mann Whitney U with Bonferroni correction for differences between groups 


\section{Perceived Social Support and Menopause Attitude}

Table 5. Differences of MSPSS and ATMS scores according some variables of women

\begin{tabular}{|c|c|c|c|c|c|}
\hline Variables & n $(\%)$ & $\begin{array}{c}\text { ATMS } \\
\text { mean } \pm \text { SD }\end{array}$ & p value & $\begin{array}{c}\text { MSPSS } \\
\text { mean } \pm \text { SD }\end{array}$ & p value \\
\hline \multicolumn{6}{|l|}{ Having chronic diseases } \\
\hline $\begin{array}{l}\text { Yes } \\
\text { No }\end{array}$ & $\begin{array}{l}31(33.3) \\
62(66.7)\end{array}$ & $\begin{array}{l}34.74 \pm 9.08 \\
37.09 \pm 6.94\end{array}$ & $\mathrm{p}=.169 \dagger$ & $\begin{array}{l}51.70 \pm 13.74 \\
56.54 \pm 10.16\end{array}$ & $\mathrm{p}=.089 \dagger$ \\
\hline \multicolumn{6}{|l|}{ Used drug } \\
\hline Yes & $31(33.3)$ & $34.51 \pm 8.16$ & & $52.96 \pm 12.54$ & \\
\hline No & $62(66.7)$ & $37.34 \pm 7.42$ & $\mathrm{p}=.099 \dagger$ & $56.26 \pm 10.88$ & $\mathrm{p}=.196 \dagger$ \\
\hline \multicolumn{6}{|l|}{ Smoking } \\
\hline No & $68(73.1)$ & $35.91 \pm 7.94$ & $\mathrm{p}=.340 t$ & $54.32 \pm 11.76$ & $\mathrm{p}=.292 t$ \\
\hline \multicolumn{6}{|l|}{ Doing physical exercise } \\
\hline Yes & $29(31.2)$ & $39.41 \pm 7.25$ & & $59.79 \pm 9.78$ & \\
\hline No & $64(68.8)$ & $34.90 \pm 7.61$ & $p=.010 t$ & $52.73 \pm 11.80$ & $p=.004 t$ \\
\hline \multicolumn{6}{|l|}{$\begin{array}{l}\text { Is there someone in need of } \\
\text { your care? }\end{array}$} \\
\hline Yes & $17(18.3)$ & $35.52 \pm 7.31$ & & $55.05 \pm 12.21$ & \\
\hline No & $76(81.7)$ & $36.48 \pm 7.88$ & $\mathrm{p}=.665 \div$ & $54.90 \pm 11.58$ & $\mathrm{p}=.941 \ddagger$ \\
\hline \multicolumn{6}{|l|}{ Perception of health } \\
\hline $\begin{array}{l}\text { Very good } \\
\text { Good }\end{array}$ & $\begin{array}{l}11(11.8) \\
60(64.5)\end{array}$ & $\begin{array}{l}44.90 \pm 6.36 \\
36.41 \pm 7.31\end{array}$ & $\mathrm{p}=.000^{\S}$ & $\begin{array}{l}62.54 \pm 9.62 \\
55.13 \pm 11.20\end{array}$ & $\mathrm{p}=. \mathbf{0 2 3} 3^{\S}$ \\
\hline Bad & $22(23.7)$ & $31.72 \pm 5.75$ & & $50.59 \pm 12.08$ & \\
\hline \multicolumn{6}{|l|}{ Dysmenorrhea } \\
\hline Yes & $29(31.2)$ & $38.06 \pm 7.74$ & & $54.72 \pm 9.69$ & \\
\hline No & $64(68.8)$ & $35.23 \pm 7.41$ & $\mathrm{p}=.138 \dagger$ & $54.68 \pm 12.27$ & $\mathrm{p}=.830 \%$ \\
\hline \multicolumn{6}{|l|}{ Menopausal status } \\
\hline Postmenopausal period & $60(64.5)$ & $34.78 \pm 7.58$ & & $53.21 \pm 12.66$ & \\
\hline Premenopausal period & $33(35.5)$ & $39.09 \pm 7.37$ & $p=.010 \dagger$ & $58.06 \pm 8.83$ & $\mathrm{p}=.054 \uparrow$ \\
\hline \multicolumn{6}{|l|}{ Menopause type $(n=57)$} \\
\hline Naturally & $49(86.0)$ & $34.77 \pm 7.69$ & & $53.26 \pm 13.35$ & \\
\hline Surgery & $8(14.0)$ & $37.50 \pm 5.18$ & $\mathrm{p}=.171+$ & $55.62 \pm 6.78$ & $\mathrm{p}=.637 \dagger$ \\
\hline \multicolumn{6}{|c|}{$\begin{array}{l}\text { Received information about } \\
\text { menopause }\end{array}$} \\
\hline Yes & $49(52.7)$ & $37.87 \pm 7.75$ & & $57.91 \pm 10.36$ & \\
\hline No & $44(47.3)$ & $34.56 \pm 7.45$ & $p=.039 \dagger$ & $51.61 \pm 12.17$ & $\mathrm{p}=.008 \dagger$ \\
\hline \multicolumn{6}{|l|}{$\begin{array}{l}\text { Spousal support with } \\
\text { menopause }\end{array}$} \\
\hline Yes & $27(29.0)$ & $37.66 \pm 8.13$ & & $55.59 \pm 11.26$ & \\
\hline No & $31(33.3)$ & $35.41 \pm 6.82$ & $\mathrm{p}=.382 \%$ & $52.96 \pm 11.80$ & $\mathrm{p}=.268 \div$ \\
\hline
\end{tabular}




\section{Discussion}

This study found that a majority of women $(66.7 \%)$, who were 45 years of age and older, had a negative attitude towards menopause. Also, the statistically positively significant correlations were found between total MSPSS scores and its subscales. These included family support subscale, friend support, and significant other support and ATMS scores of women. Our study findings determined that strong perceived social support positively affects women's attitudes towards menopause. Another study found that $92 \%$ of Italian women going through menopause accepted it as a normal phase of life, and more than $40 \%$ thought it to be a good experience (Donati et al., 2009). A previous study indicated that post-menopausal and non-menopausal Taiwanese women have a higher awareness of menopause than other Asian women (Pan et al., 2002). In Bahraini women displayed a considerable range of attitudes towards menopause, ranging from neutral to positive; premenopausal women had more negative attitudes towards menopause than perimenopausal or postmenopausal Bahraini women (Jassim and Al-Shboul, 2008). In Iran was revealed that most women $(71 \%)$ had a neutral attitude and $22.8 \%$ of them had positive attitudes towards menopause (Ghorbani et al., 2014). The metaanalysis of this same study found that $58 \%$ of Iranian women had neutral attitudes, $25 \%$ of them had positive attitudes, and $17 \%$ had negative attitudes towards menopause (Bahri et al., 2016). The Turkish study showed that more than half of the women had negative attitudes towards menopause (Erbil et al., 2012). In Turkey, a study using an attitude towards menopause scale in which they found that women had negative attitudes towards menopause (Tortumluoğlu and Erci, 2004), however, another study revealed women's positive attitudes towards menopause (Çoban et al., 2008). Results in this study concerning attitudes towards menopause were similar to some research findings (Tortumluoğlu and Erci 2004; Erbil et al., 2012; Ghorbani et al., 2014; Bahri et al., 2016) yet different from other studies (Jassim and Al-Shboul, 2008; Çobanet al., 2008). Differences in results may be due to women's various educational, cultural, and ethnic characteristics.

For many women, changes in their family and social environments during menopause can create a crisis leading to relationship conflicts. These issues are not just a concern for women, but also for their families and social and business communities. These changes can affect their work, management decisions, and their efficiency (Karlidere and Özşahin, 2008). Having a positive and strong social support system is a positive factor for avoiding the development of emotional or psychiatric problems in the menopausal period (Karlıdere and Özşahin, 2008). Adequate and strong social support can help women address the grief of the losses experienced during the climacteric period (Zhang et al., 2016). It was indicated that many symptoms of menopause can be prevented by providing women and their families with knowledge about menopause and its management (Qazi, 2006). Studies have reported that women with less family support have been found to have more severe mental health problems and irritability during the transitional period to menopause (Çifcili et al., 2009). A study was found that over two-thirds of women experiencing symptoms attributed to menopause discussed their symptoms with friends and family (Duffy et al., 2012). A focus group study of menopausal women in the United Kingdom indicated that talking with others about menopause, feeling supported by their experience, and discussing the different management strategies can help to ease the menopausal symptoms (Duffy et al., 2011). Depressive symptoms are associated with low social support scores (Li et al., 2008), poor social support increases the risk of anxiety and depression (Binfa et al., 2004), depression is significantly and negatively associated with a woman's social support during menopause (Sadat, Abbaszadeh and Taebi, 2009). In a study noted that middle-aged woman and her family with comprehensive information on menopause would be better prepared to experience this period with less fear and better control (Hunter and Rendall, 2007).

The following factors played a statistically significant part in a woman's more positive attitude towards menopause: being age 50 and younger, higher education level, working outside the home, being single, having normal BMI, and being in a nuclear family. Other factors were a husband with higher education, a husband who is a civil servant, having a higher income perception, living in a province, doing physical exercise, having a positive health perception, and being premenopausal, being informed about menopause, and the differences between groups were statistically significant (see Table 4,5). The "transition phase" occurs with greater ease in working women (Nijs, 1998). A previous study reported that menopausal status, educational level, marital status, place of residency, and employment were not associated with women's 
attitudes towards menopause (Ghorbaniet al., 2014). A moderate level of physical activity was associated with reduced psychosocial and physical menopause symptoms in perimenopausal Korean women (Kim et al., 2014). In rural Iranian women had a more negative attitude towards menopause than urban Iranian women (Khademi and Cooke, 2003). Older women with a higher educational level had more positive attitudes towards menopause (Kısa et al., 2012). In addition, there was no statistically significant difference between employed women, parity, marital status and attitudes towards menopause of women. These results were consistent with the literature.

In this study, the MSPSS scores were higher than for other women in the following categories: age 50 and under, higher education level, working, higher income perception, single, living in a province, doing physical exercise, and having a positive health perception. The differences between groups were statistically significant (see Table 4,5). Inadequate social support increases the frequency of menopausal symptoms during menopause (Karlidere and Özşahin, 2008). The findings of this study indicated a significant relationship between the woman's level of education and perceived social support. Women with high education levels have a better understanding of perceived social support, which is concordant with the results of studies (Najafabadi et al., 2015; Rambod and Rafii, 2010). This study revealed a significant relationship between perceived social support and marital status; married women reported the worst perceived social support. Furthermore, it was highlighted a significant relationship between perceived social support and age, marital status, education level, job status, number of children, number of childbirths, and residence status of Iranian postmenopausal women (Najafabadi et al., 2015). Married women with a higher education level reported better perceived social support. Husbands who demonstrated support for their wives during menopause significantly impacted their wives' health in a positive manner. Indeed, the quality of the marital relationship was also a parameter of women's health (Brennan et al., 2011). Studies have shown that a woman's marriage and relationship with her husband play an important role in dealing with complaints of this period (Montero et al., 1993; Koster and Davidsen, 1993; Bayraktar and Uçanok, 2002). A previous study in Turkey showed that the severity of menopausal complaints might be related to the husbands' attitudes towards menopause (Aksu et al., 2011). It was reported on the necessity for educational interventions to help men better support their wives in passing through menopause (Hidiroglu et al., 2014). A study found taht one-third of the husbands of perimenopausal women believed they were not supportive, but the majority said they provided mostly emotional support Mansfield et al., 2003). Most husbands had some information about menopause, but more than one in four knew little or nothing. A lack of information, the negative effects of their wives'menopausal transition, and their own stresses may have interfered with husbands' ability to provide social support (Mansfield et al., 2003). Men with adequate knowledge about menopause health can help improve their spouses'quality of life in this period (Bahri et al., 2016).

Limitations of the study are that it was a crosssectional study and a small sample size confined to specific Turkish women. The study sample was performed in a public hospital in the northeast of Turkey. Therefore, the results of this study can be generalized only to the subjects of this study.

\section{Implications for Practice and/or Policy}

This study found the majority of women are negative attitudes toward menopause, women's perceived social support during menopause is at low levels. The results determined that strong perceived social support positively affects women's attitudes towards menopause. Informational programs need to be focused on developing positive attitudes in both women and men to help couples and strengthening women's social support and preparation during menopause. Informational programs need to be focused on developing positive attitudes in both women and men to help couples and families more easily navigate the changes which occur during this time of a woman's life. Educational programs on this important topic need to be developed by both health professionals and healthcare policy makers.

\section{Conclusion}

In this study, the majority of women age 45 and older ages had negative attitudes toward menopause. Women's perceived social support during menopause was at low levels. Positive significant correlations were found between the family support subscale, friend support, significant other support, total MSPSS scores and attitude towards menopause scale score of women. Furthermore, significantly higher attitude scores towards menopause were obtained by women who were age 50 and under, had a higher education level, were working, single, had 
normal BMI, had a nuclear family, had a husband, had a husband with higher education, had a husband who was a civil servant, had higher income perception, were living in province, did physical exercise, had a positive health perception, were in the premenopausal period, and had information about menopause. The MSPSS scores were higher for women who counted themselves in the following categories: age 50 and under, higher education level, civil servant, living in a province, higher income perception, single, doing physical exercise, positive health perception, in premenopause period and informed about menopause.

In conclusion, women, as well as society in general, should have access to current and accurate information concerning women's health issues. In particular, attention is needed regarding the topics of women's menstrual health to include premenopause, perimenopause, and finally full menopause at which point menses have ceased continously for a period of twelve months. Health professionals have a major role in strengthening women's social support and preparation during menopause. Therefore, educational programs on this important topic need to be developed by both health professionals and healthcare policy makers. Education needs to emphasize the importance of social support for women to strengthen positive attitudes towards the natural changes which will occur. Informational programs need to be focused on developing positive attitudes in both women and men to help couples and families more easily navigate the changes which occur during this time of a woman's life.

\section{Acknowledgements}

The authors thank to women who participated to this study and English specialist PM Kanuer. Also, the authors thank to Scientific Researches Project Coordination Department, Ordu University supported as financial for the congress participation.
Ethics Committee Approval: Participants were informed about the purpose of the research before starting the study. Confidentiality and anonymity of data of participants were guaranteed and verbal permission was taken from participants. It was taken written permission of the management of the institution to do research. The study was carried out a proper research to Helsinki Declaration Principles.

Peer-review: Externally peer-reviewed.

Author Contributions: Concept - NE and MG; Design NE and MG; Supervision NE; Materials - NE and MG; Data Collection and/or Processing - NE and MG; Analysis and/or Interpretation - NE; Literature Review - NE and MG; Writing - NE and MG; Critical Review - NE and MG.

Conflict of Interest: No conflict of interest was declared by the author.

Financial Disclosure: The author declared that this study has received no financial support.

\section{References}

Adewuyi TDO, Akinade EA. Perception and attitudes of Nigerian women towards menopause. Procedia-Social and Behavioral Sciences, 2010;5: 1777-82.

Akkuzu G, Örsal Ö, Kecialan R. Women's attitudes towards menopause and influencing factors. Turk J Med Sci, 2009; 29:666-74.

Aksu H, Sevinçok L, Küçük M, Sezer SD, Ogurlu N. The attitudes of menopausal women and their spouses towards menopause. Clin Exp Obstet Gynecol , 2011;38:251-255.

Bahri N, Latifnejad Roudsari R, Tohidinik HR, Sadeghi R. Review Article Attitudes Towards Menopause Among Iranian Women: A Systematic Review and Meta-Analysis. Iran Red Crescent Med J, 2016;18:1-12.

Bayraktar R, Uçanok Z. Menopoza ilişkin yaklaşımların ve kültürlerarası çalışmaların gözden geçirilmesi. Aile ve Toplum Dergisi 2002; 2: 5-12.

Binfa L, Castelo-Branco C, Blümel JE, Cancelo MJ, Bonilla H, Munoz I, et al. Influence of psychosocial factors on climacteric symptoms. Maturitas 2004; 48, 425-31.

Brennan SL, Pasco JA, Urquhart DM, Oldenburg B, Wang Y, Wluka AE. Association between socioeconomic status and bone mineral density in adults: a systematic review. Osteoporos Int, 2011; 22: 517-27. 
Cheng MH, Wang SJ, Wang PH, Fuh JL. Attitudes towards the menopuse among middle-aged women: A community survey on an Island of Taiwan. Maturitas, 2005; 52: 348-55.

Çifcili SY, Akman M, Demirkol A, Unalan PC, Vermeire E. I should live and finish it: A qualitative inquiry into Turkish women's menopause experience. BMC Fam Pract, 2009; 10: 1-9.

Çoban A, Nehir S, Demirci H, Özbaşaran F, İnceboz $\mathrm{U}$. The impact on menopausal symptoms of marital adjustment and attitude toward menopausal of married women in the climacteric period. Firat University Medical Journal of Health, 2008; 22: 343-349.

Donati S, Cotichini R, Mosconi P, Satolli R, Colombo C, Liberati A. Menopause: knowledge, attitude and practice among Italian women. Maturitas, 2009;63: 246-252.

Duffy OK, Iversen L, Hannaford PC. The impact and management of symptoms experienced at midlife: a community based study of women in northeast Scotland. BJOG, 2012;119: 554-64.

Duffy OK, Iversen L, Hannaford PC. The menopause "It's somewhere between a taboo and a joke" A focus group study. Climacteric, 2011;14: 497-05.

Erbil N, Boyacı S, Kurt İ, AkdoğanY, Kaya İ. A Turkish study on menarche and menstrual experiences and their effects on attitudes towards menopause. Int J Nurs Pract, 2012; 18: 107-116.

Eker D, Arkar H. Factor structure, reliability and validity to the multidimensional scale of social support. Turk Psikoloji Dergisi 1995; 10, 45-55.

Ghorbani R, Nassaji M, Shahbazi A, Tabar SB, Rahaei F. Attitudes toward menopause among middle-aged women in Semnan, Iran. J Egypt Public Health Assoc , 2014; 89: 42-5.

Hidiroglu S, Tanriover O, Ay P, Karavus M. A qualitative study on menopause described from the man's perspective. J Pak Med Assoc, 2014;64: 1031-6.

Huffman SB, Myers JE, Tingle LR, Bond LA. Menopause symptoms and attitudes of African American women: closing the knowledge gap and expanding opportunities for counselling. Journal of Counseling \& Development, 2005;83: $48-56$.

Hunter M, Rendall M. Bio-psycho-socio-cultural perspectives on menopause. Best Pract Res Clin Obstet Gynaecol, 2007;21: 261-274.
International Menopause Society. Menopause terminology.

http://www.imsociety.org/menopause_terminolo gy.php, 2016. Retrieved from: September 10, 2016.

Jassim GA, Al-Shboul Q. Attitudes of Bahraini women towards the menopause: implications for health care policy. Maturitas, 2008; 59: 358-372.

Karlıdere T, Özşahin A. The relationship of menopausal symptomatology with anxiety and depression levels and social supports. Klinik Psikiyatri, 2008; 11: 159-66.

Khademi S, Cooke MS. Comparing the attitudes of urban and rural Iranian women toward menopause. Maturitas, 2003; 46: 113-21.

Kısa S, Zeyneloğlu S, Özdemir N. Examination of midlife women's attitudes toward menopause in Turkey. Nursing and Health Sciences, 2012; 14: 148-155.

Kim, M.J., Cho, J. Ahn, Y. Yim, G., \& Park, H.Y. (2014). Association between physical activity and menopausal symptoms in peimenopausal women. BMC Women's Health, 14,122.

Koç Z, Sağlam Z. The determination of the symptom and the attitudes of women in climacterium period related to menopause. Journal of Social Policy Studies, 2008; 15: 100112.

Koster A, Davidsen M. Climacteric complaints and their relation to menopausal development: A retrospective analysis. Maturitas, 1993; 17: 155166.

Li Y, Yu Q, Ma L, Sun Z, Yang X. Prevalence of depression and anxiety symptoms and their influence factors during menopausal transition and postmenopause in Beijing city. Maturitas, 2008; 61: 238-242.

Mansfield PK, Koch PB, Gierach G. Husbands' support of their perimenopausal wives. Women Health, 2003; 38: 97-112.

Montero I, Ruiz I, Hernandez I. Social functioning as a significant factor in women's help- seeking behavior during the climacteric period. Soc Psychiatry Psychiatr Epidemiol, 1993;28: 178183.

Najafabadi MT, Kalhori H, Javadifar N, Haghighizadeh MH. Association Between Perceived Social Support and Depression in Postmenopausal Women. Jundishapur J Chronic Dis Care, 2015;4: 12-17.

Neugarten BL, Wood V, Kraines RJ, Loomis B.Women's attitudes towards menopause. Vita Humana, 1963; 6: 140-151. 
Nijs P. Counseling of the climacteric woman. diagnostic difficulties and therapeutic possibilities. Eur J Obstet Gynecol Reprod Biol 1998; 81: 273-276.

Pan HA, Wu MH, Hsu CC, Yao BL, Huang, KE. The perception of menopause among women in Taiwan. Maturitas, 2002;41: 269-274.

Qazi RA. Age, pattern of menopause, climacteric symptoms and associated problems among urban population of Hyderabad, Pakistan. Journal of the College of Physicians Surgeons Pakistan, 2006; 16: 700-703.

Rambod M, Rafii F. Perceived social support and quality of life in Iranian hemodialysis patients. Journal of Nursing Scholarship, 2010;42: 242249.

Sadat Z, Abbaszadeh F, Taebi M. The Relationship between social support and depression in postmenopausal women. Maturitas, 2009; 63: 132.

Şentürk Erenel A, Gölbaşı Z, Kavlak T, Dilbaz S. Relationship between menopausal symptoms and sexual dysfunction among married Turkish women in 40-65 age group. Int J Nurs Pract, 2015; 21: 575-583.

Taylor SE. Social Support: A Review. (Ed: Howard S. Friedman) The Oxford Handbook of Health Psychology. Published by Oxford University Press, Inc., New York, 2011.

Taşkın L. Doğum ve Kadın Hastalığı Hemşireliğii. Ankara: Akademisyen Kitabevi, Ankaar, 2015.

Tortumluoğlu G. Asyalı ve Türk Kadınlarında Menopoz. Journal of Human Sciences, 2004;111.

Tortumluoğlu G, Erci B. The effectiveness of planned health education given to climacteric women on the menopausal symptoms and attitude, and health behaviors. Journal of Human Sciences, 2004;1:1-22.

Uçanok Z, Bayraktar R. Farklı yaş gruplarındaki kadınlarda menopoza ilişkin belirtilerin, tutumların ve yaşama bakış açısının incelenmesi]. 3P Dergisi: Psikoloji, Psikiyatri, Psikofarmokoloji, 1996; 4: 11-20.

Vural PI, Yangin HB. Perception of menopause: The Turkish and German women's comparison. Gümüşhane University Journal of Health Sciences, 2016; 5: 7-15.

Yoo GJ, Levine EG, Aviv G, Ewing C, Au A. Older women, breast cancer, and social support. Support Care Cancer, 2010; 18: 1521-1530.
Zhang Y, Zhao X, Leonhart R, Nadig M, Hasenburg A, Wirsching M,et al. A cross-cultural comparison of climacteric symptoms, selfesteem, and perceived social support between Mosuo women and Han Chinese women. Menopause, 2016; 23: 784-91.

Zimet GD, Dahlem NW, Zimet SG, Farley GK. The Multidimensional Scale of Perceived Social Support. Journal of Personality Assessment, 1988; 52: 30-41. 